\title{
The Effect of Habitat Conditions on the Activity of Enzymes and Content of Metabolites of the Ascorbate-Glutathione Cycle in Plantago media Leaves
}

\author{
Ekaterina V. Silina* and Tamara K. Golovko \\ Institute of Biology of Komi Scientific Centre \\ of the Ural Branch of RAS \\ Syktyvkar, Russian Federation
}

Received 18.03.2021, received in revised form 12.08.2021, accepted 31.08.2021

\begin{abstract}
The ascorbate-glutathione cycle (AGC) is a metabolic pathway that detoxifies $\mathrm{H}_{2} \mathrm{O}_{2}$, which is a reactive oxygen species produced as a waste product in metabolism. The cycle involves the antioxidant metabolites - ascorbate, glutathione, and NADPH, as well as enzymes linking them. We studied the effect of habitat conditions on the activity of enzymes and contents of metabolites of the ascorbateglutathione cycle in Plantago media leaves. The experimental plants grew on the floodplain meadow: on the sparsely vegetated coastal edge (Site 1) and in the grass stand in the central part of the meadow (Site 2). The hoary plantain plants growing in Site 1 received twice more light than the plants in Site 2. The ascorbate and glutathione concentrations in leaves of the well-lit plants were 2-3 times higher than in shaded plants. The maximal levels of these metabolites were observed at midday, when light intensity and air temperature were increased, and relative humidity was decreased. The activity of AGC enzymes was changing similarly to the metabolite contents. As a result, the leaves of hoary plantain plants from the sites with different light levels did not significantly differ in their hydrogen peroxide concentrations. Our data suggest that the environmental conditions and, above all, the light intensity fine-tune the operation of AGC in plant leaves.
\end{abstract}

Keywords: Plantago media, ascorbate-glutathione cycle, enzyme activity, metabolite content, light, environmental conditions.

Acknowledgements. This work was conducted within the framework of the state budget research, development, and technological work «Physiology and Stress Resistance of Photosynthesis of Plants and Poikilohydric Photoautotrophs in the North» (No. AAAA-A17-117033010038-7).

\footnotetext{
(C) Siberian Federal University. All rights reserved

This work is licensed under a Creative Commons Attribution-NonCommercial 4.0 International License (CC BY-NC 4.0).

* Corresponding author E-mail address: silina@ib.komisc.ru

ORCID: 0000-0002-9632-3431 (Silina E.V.); 0000-0002-7993-9541 (Golovko T.K.)
} 


\title{
Влияние условий обитания на активность ферментов и содержание метаболитов аскорбат-глутатионового цикла в листьях Plantago media
}

\author{
Е. В. Силина, Т. К. Головко \\ Институт биологии Коми научного иентра \\ Уральского отделения РАН \\ Российская Федерация, Сыктывкар
}

\begin{abstract}
Аннотация. Аскорбат-глутатионовый цикл (АГЦ) представляет собой метаболический путь, осуществляющий детоксификацию $\mathrm{H}_{2} \mathrm{O}_{2}$ в растительных клетках. В цикле участвуют низкомолекулярные антиоксиданты аскорбат и глутатион, НАДФН и ряд ферментов (аскорбатпероксидаза, дегидроаскорбатредуктаза, глутатионредуктаза). Мы исследовали закономерности изменения активности ферментов и содержания метаболитов АГЦ в листьях Plantago media (подорожник средний) в зависимости от условий местообитания. Растения произрастали на пойменном лугу: на слабо покрытой растительностью песчаной бровке ближе к реке (участок 1) и в травостое в центре луга (участок 2). Растения участка 1 получали вдвое больше света, чем растения участка 2. Выявили, что листья хорошо освещаемых растений содержали в 2-3 раза больше аскорбата и глутатиона, чем листья затененных растений. Максимальное накопление фонда этих метаболитов наблюдалось в полдень, когда освещенность и температура среды повышались, а относительная влажность воздуха снижалась. Уровень активности ферментов в течение дня изменялся комплементарно содержанию метаболитов. В результате хорошо освещенные и затененные растения не различались существенно по содержанию пероксида водорода в листьях. В целом наши данные показывают, что функционирование метаболического пути, участвующего в поддержании редокс-состояния фотосинтезирующих клеток, зависит от условий среды и, прежде всего, интенсивности света, тонко регулирующего активность ферментов и накопление метаболитов АГЦ.
\end{abstract}

Ключевые слова: Plantago media, аскорбат-глутатионовый цикл, ферменты, метаболиты, свет, условия среды.

Благодарности. Работа выполнена в рамках Госбюджетной научно-исследовательской, опытно-конструкторской и технологической работы «Физиология и стресс-устойчивость фотосинтеза растений и пойкилогидрических фотоавтотрофов в условиях Севера» (№ AАAA-A17-117033010038-7). 
Цитирование: Силина, Е.В. Влияние условий обитания на активность ферментов и содержание метаболитов аскорбатглутатионового цикла в листьях Plantago media / Е. В. Силина, Т. К. Головко // Журн. Сиб. федер. ун-та. Биология, 2021. 14(3). C. 265-273. DOI: 10.17516/1997-1389-0350

\section{Introduction}

Plants are constantly adapting to changing environmental conditions and, above all, any light that they are exposed to. The most important source of reactive oxygen species (ROS) in photosynthetic cells is the chloroplast electron transport chain. If too much energy is absorbed relative to the requirements of the photosynthetic process, the generation of ROS is increased. High light, especially when combined with other stressors, leads to the development of photo-oxidative stress and photoinhibition (Foyer, 2018). In the course of evolution, plants have developed different mechanisms to adapt to high photosynthetic photon flux density. They can adjust the angle of their leaves and chloroplast localization in the cells to minimize exposure, decrease chlorophyll content, and dissipate energy via the xanthophyll cycle and other energy dissipation processes (Bukhov et al., 2001; Vogelmann, Gorton, 2014; Ruban, 2015). Plants can prevent excessive ROS accumulation and maintain the cell redox balance by regulating the antioxidant system activity (Halliwell, 2006; Foyer, 2018).

The ascorbate-glutathione cycle (AGC) is an important metabolic pathway that functions in the cytosol, mitochondria, plastids, and peroxisomes
(Asada, 2000). The cycle involves ascorbate (Asc), glutathione (GSH), NADPH, and enzymes that bind these metabolites (Fig. 1). Ascorbate peroxidase (APX) uses two ascorbate molecules to reduce hydrogen peroxide $\left(\mathrm{H}_{2} \mathrm{O}_{2}\right)$ to water with the concomitant formation of monodehydroascorbate (MDA). MDA is a radical with a short life-time, and can be spontaneously oxidized to dehydroascorbate (DHA) or reduced by the NADPH-dependent enzyme monodehydroascorbate reductase (MDAR) to ascorbate. DHA is reduced rapidly to ascorbate by dehydroascorbate reductase (DHAR), the process involving reducing equivalents glutathione. NADPH and glutathione reductase (GR) take part in the reduction of oxidized glutathione (GSSG) in the cell (Foyer, Noctor, 2011).

AGC is a key mechanism for regulation of $\mathrm{H}_{2} \mathrm{O}_{2}$ content in plant cells (Foyer, Noctor, 2011). $\mathrm{H}_{2} \mathrm{O}_{2}$ is produced mainly during photosynthetic and photorespiratory processes, especially when plants are exposed to strong light. This relatively stable compound is supposed to play a central role in orchestrating plant metabolism, as it can affect expression of many genes and regulate many processes (Neill et al., 2002; Foyer, 2018).

The aim of our study was to estimate the effects of habitat conditions on the activities

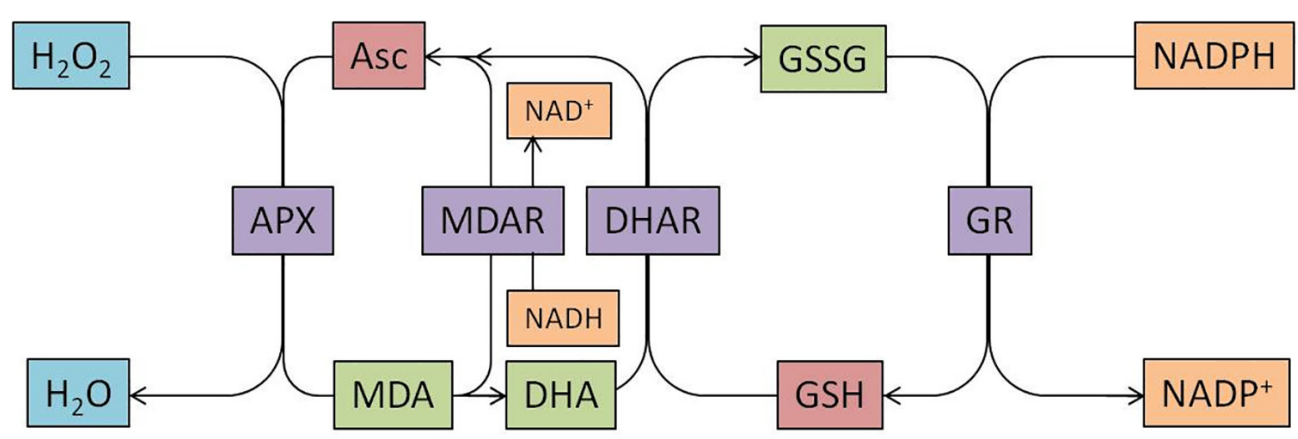

Fig 1. A scheme of the glutathione-ascorbate cycle (Foyer-Halliwell-Asada pathway)

$$
-267-
$$


of enzymes and contents of metabolites of the ascorbate-glutathione cycle in Plantago media L. leaves. For this, we assessed the daytime changes of ascorbate and glutathione pools and hydrogen peroxide content. We also determined the activities of ascorbate peroxidase, dehydroascorbate reductase, and glutathione reductase.

\section{Materials and methods}

Plant material

$P$. media (hoary plantain) is a perennial herbaceous plant of Plantaginaceae family. Experimental plants grew in the Vym river floodplain meadow (62 16'19"N, 50³9'29"E). Plants grew on the sparsely vegetated coastal edge (Site 1) and in the grass stand in the central part of the meadow (Site 2). The soil of the meadow is well-drained sod-layered sandy-sandy loam.

The research was conducted in early July 2018, when plants were in the beginning of the budding stage. We collected fully developed leaves from the middle part of the $P$. media rosette during the day. We placed the samples from 15-25 plants in a dewar with liquid nitrogen, delivered them to the laboratory, and stored at $-70{ }^{\circ} \mathrm{C}$ prior to the analysis.

Photosynthetic photon flux density (PPFD, $\left.\mu \mathrm{mol} \mathrm{m} \mathrm{m}^{-2} \mathrm{~s}^{-1}\right)$, temperature $\left(\mathrm{T},{ }^{\circ} \mathrm{C}\right)$ and relative humidity $(\mathrm{RH}, \%)$ at the level of the hoary plantain leaves were measured with sensors of portable weather station LI-1400 (LI-COR, USA).

\section{Biochemical analyses}

Ascorbate peroxidase (EC1.11.1.11) activity was determined according to Nakano and Asada (1981). This method is based on measuring the optical density of the solution during the ascorbate oxidation. Dehydroascorbate reductase (EC1.8.5.1) activity was determined by calculating the rate of dehydroascorbate reduction (Hossain, Asada, 1984). The activity of glutathione reductase (EC1.8.1.7) was determined by NADPH oxidation kinetics in the presence of oxidized glutathione (Foyer, Halliwell, 1976). Soluble protein content was determined according to Bradford (1976). All manipulations with the enzymes were performed at $4{ }^{\circ} \mathrm{C}$.

The ascorbate content was determined based on the reduction of $\mathrm{Fe}^{3+}$ to $\mathrm{Fe}^{2+}$ (Kampfenkel et al., 1995). The glutathione content was determined according to Queval and Noctor (2007). The $\mathrm{H}_{2} \mathrm{O}_{2}$ content was determined according to Bellincampi et al. (2000).

\section{Statistical analysis}

Statistical analysis of the data was performed using the Statistica 6.1 software («StatSoft Inc.», U.S.A.). Data are shown as the mean \pm standard error (SE). Normal distribution was confirmed using the Shapiro-Wilk test. Means were compared using analysis of variance (one-way ANOVA) and Duncan's test. A value of $P<0.05$ was considered statistically significant.

\section{Results}

Microclimatic conditions in plant habitats

The $P$. media species is widely represented in the local flora; it exhibits high morphophysiological plasticity and ability to form phenotypes adapted to various environmental conditions. Hoary plantain plants inhabit floodplain meadows, roadsides, and sparse forests, and this species is a pioneer on shallows and limestone outcrops. We studied plants growing in different locations of the floodplain meadow.

Hoary plantain plants growing in Site 1 received more light and heat than those in Site 2 (Fig. 2). In this site at midday, the average PPFD at the level of the hoary plantain leaves was 600 $700 \mu \mathrm{mol} \mathrm{m}{ }^{-2} \mathrm{~s}^{-1}$. The air warmed up to $23-25^{\circ} \mathrm{C}$. The plant leaves in Site 2 received 2-3 times less light. The air temperature was also $3-4{ }^{\circ} \mathrm{C}$ 

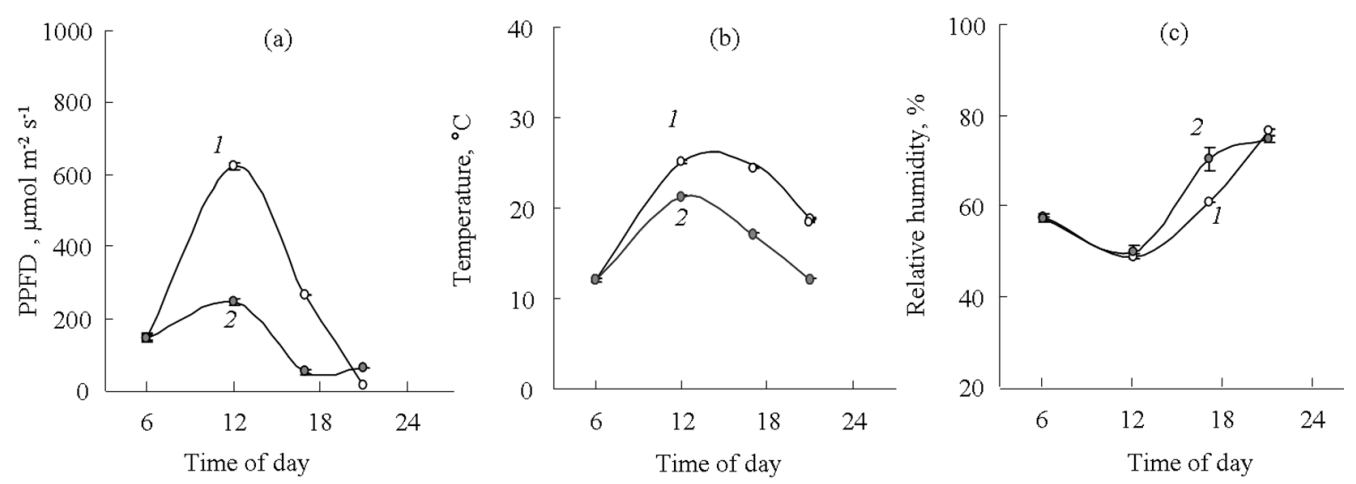

Fig. 2. Diurnal dynamics of photosynthetic photon flux density (a), air temperature (b), and relative humidity (c) in Plantago media habitats: (1) the sparsely vegetated coastal edge (Site 1) and (2) the grass stand in the central part of the meadow (Site 2)

lower than in Site 1. The relative humidity was distinctly higher in the second half of the day in Site 2.

\section{Ascorbate and glutathione contents}

Total ascorbate concentration increased by $17 \%$ during the first half of the day in leaves of plants from Site 1 (Table 1). The reduced ascorbate dominated in the total ascorbate pool, amounting to $80 \%$ on average. Ascorbate concentration decreased slightly after midday. Ascorbate concentration in the leaves of plants from Site 2 was lower by a factor of more than two compared to plants in Site 1 and increased slightly after midday.

A $30-40 \%$ increase in reduced glutathione concentration was observed during the first half of the day in hoary plantain leaves from both sites (Table 2). The reduced GSH content decreased 3.5 times in the leaves from Site 1 by the nighttime. Oxidized glutathione constituted $1 \%$ of the total glutathione pool in the daytime. A significant increase in the level of oxidized glutathione concentration was observed in the evening. The daily changes of the glutathione level in plant leaves from Site 2 were similar, but the reduced GSH concentration was lower.

\section{Level of AGC enzyme activities}

The ascorbate peroxidase (APX) activity changed markedly during the day in the leaves of plants from Site 1 (Fig. 3a). We observed a 1.3-fold increase in APX activity from early morning to midday and the subsequent decrease.

Table 1. Reduced and oxidized ascorbate concentrations in the leaves of the hoary plantain plants, $\mu \mathrm{mol} \mathrm{g}^{-1} \mathrm{dry}$ weight

\begin{tabular}{ccccccc}
\hline \multirow{2}{*}{$\begin{array}{c}\text { Time of } \\
\text { day }\end{array}$} & $\begin{array}{c}\text { Reduced } \\
\text { ascorbate }\end{array}$ & $\begin{array}{c}\text { Oxidized } \\
\text { ascorbate }\end{array}$ & Total content & $\begin{array}{c}\text { Reduced } \\
\text { ascorbate }\end{array}$ & $\begin{array}{c}\text { Oxidized } \\
\text { ascorbate }\end{array}$ & Total content \\
\cline { 2 - 7 } & $29.1 \pm 0.6^{\mathrm{a}^{*}}$ & $5.5 \pm 0.6^{\mathrm{a}}$ & $34.0 \pm 0.6^{\mathrm{a}^{*}}$ & $12.0 \pm 0.3^{\mathrm{a}}$ & $5.0 \pm 0.6^{\mathrm{a}}$ & $17.0 \pm 0.5^{\mathrm{a}}$ \\
13 & $34.3 \pm 1.5^{\mathrm{b}^{*}}$ & $8.4 \pm 0.8^{\mathrm{b}^{*}}$ & $41.4 \pm 2.0^{\mathrm{b}^{*}}$ & $12.4 \pm 0.2^{\mathrm{a}}$ & $4.8 \pm 0.4^{\mathrm{a}}$ & $17.7 \pm 0.2^{\mathrm{a}}$ \\
22 & $30.8 \pm 0.6^{\mathrm{a}^{*}}$ & $8.3 \pm 1.2^{\mathrm{b}^{*}}$ & $39.9 \pm 1.3^{\mathrm{b} *}$ & $13.9 \pm 0.6^{\mathrm{b}}$ & $5.4 \pm 0.7^{\mathrm{a}}$ & $19.3 \pm 1.0^{\mathrm{b}}$ \\
\hline
\end{tabular}

Asterisks indicate significance of differences of Site 1 from Site 2. Different superscript letters denote statistically significant changes throughout the day $(P<0.05$; Dunkan-test). 
Table 2. Reduced and oxidized glutathione concentrations in the leaves of hoary plantain plants, $\mu \mathrm{mol}$ GSH $\mathrm{g}^{-1}$ dry weight

\begin{tabular}{ccccccc}
\hline \multirow{2}{*}{$\begin{array}{c}\text { Time of } \\
\text { day }\end{array}$} & \multicolumn{3}{c}{ Site 1} & \multicolumn{2}{c}{ Site 2} \\
\cline { 2 - 6 } & $\begin{array}{c}\text { Reduced } \\
\text { glutathione }\end{array}$ & $\begin{array}{c}\text { Oxidized } \\
\text { glutathione }\end{array}$ & Total content & $\begin{array}{c}\text { Reduced } \\
\text { glutathione }\end{array}$ & $\begin{array}{c}\text { Oxidized } \\
\text { glutathione }\end{array}$ & Total content \\
\hline 6 & $5.6 \pm 0.9^{\mathrm{b}^{*}}$ & $0.05 \pm 0.01^{\mathrm{a}}$ & $5.7 \pm 0.5^{\mathrm{a}^{*}}$ & $2.2 \pm 0.5^{\mathrm{a}}$ & $0.08 \pm 0.01^{\mathrm{a}}$ & $2.3 \pm 0.3^{\mathrm{a}}$ \\
13 & $9.3 \pm 1.5^{\mathrm{a}^{*}}$ & $0.09 \pm 0.01^{\mathrm{a}^{*}}$ & $9.4 \pm 0.4^{\mathrm{b}^{*}}$ & $3.2 \pm 1.3^{\mathrm{b}}$ & $0.13 \pm 0.01^{\mathrm{a}}$ & $3.3 \pm 0.1^{\mathrm{b}}$ \\
22 & $2.6 \pm 0.1^{\mathrm{b}}$ & $0.45 \pm 0.01^{\mathrm{b}^{*}}$ & $2.9 \pm 0.5^{\mathrm{c}}$ & $1.9 \pm 0.2^{\mathrm{ab}}$ & $0.51 \pm 0.01^{\mathrm{b}}$ & $2.4 \pm 0.1^{\mathrm{a}}$ \\
\hline
\end{tabular}

Asterisks indicate significance of differences of Site 1 from Site 2. Different superscript letters denote statistically significant changes throughout the day $(P<0.05$; Dunkan-test)
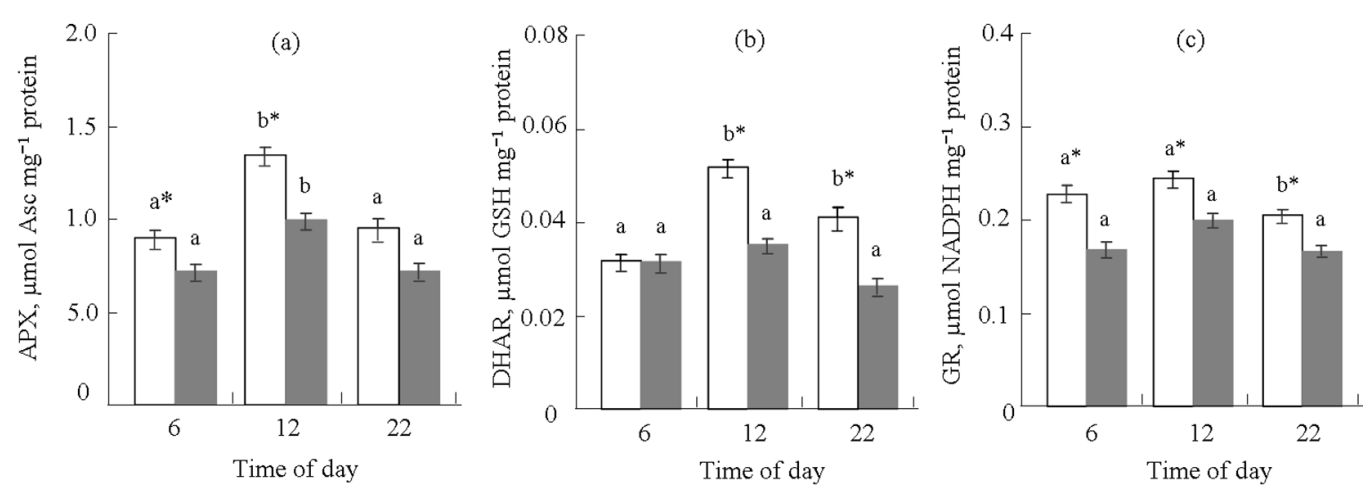

Fig. 3. Ascorbate peroxidase (a), dehydroascorbate reductase (b), and glutathione reductase activities (c) in the leaves of hoary plantain plants from Site 1 (light columns) and from Site 2 (dark columns). Asterisks indicate significance of differences of Site 1 from Site 2. Different superscript letters denote statistically significant changes throughout the day $(P<0.05$; Dunkan-test)

The daytime course of the APX activity in the leaves of hoary plantain from Site 2 was similar, but the level of the APX activity was lower by $20 \%$.

The level of dehydroascorbate reductase (DHAR) activity increased from early morning to midday by $40 \%$ in the leaves of plants from Site 1 (Fig. 3b). No significant daily changes in the activity of this enzyme were observed in plants from Site 2. The level of the DHAR activity in leaves of hoary plantain from Site 2 was lower compared to plants from Site 1.

The level of glutathione reductase (GR) activity did not change during the day in the leaves of plants from Site 2, while in the plants from Site 1 it decreased by $30 \%$ by the nighttime (Fig. 3c). During the daytime, the level of the
GR activity in leaves of plants from Site 1 was slightly higher than in the leaves from Site 2.

\section{Hydrogen peroxide content}

The habitat conditions did not have a significant effect on the $\mathrm{H}_{2} \mathrm{O}_{2}$ concentration in the leaves of hoary plantain (Fig. 4). In both sites, the concentration of $\mathrm{H}_{2} \mathrm{O}_{2}$ in the daytime was $30-40 \%$ higher than in the nighttime, but plant leaves from Site 2 contained slightly less hydrogen peroxide compared to plants from Site 1.

\section{Discussion}

Peroxide is produced mainly during photosynthetic and photorespiratory processes, especially when plants are exposed to strong light. From our experiments it is obvious that 


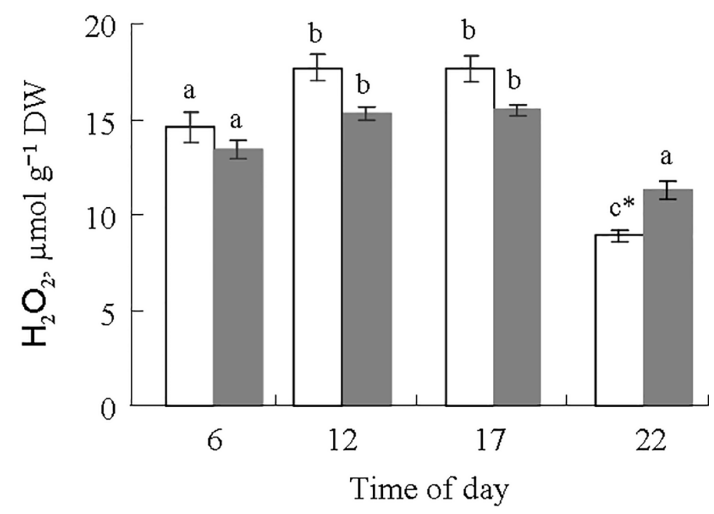

Fig. 4. Hydrogen peroxide concentration in the leaves of hoary plantain plants from Site 1 (light columns) and from Site 2 (dark columns). Asterisks indicate significance of differences of Site 1 from Site 2. Different superscript letters denote statistically significant changes throughout the day $(P<0.05$; Dunkan-test $)$

the leaves of hoary plantain plants from the sites with high and low light did not differ significantly in hydrogen peroxide concentration (Fig. 4). Presumably, this may be the result of ascorbateglutathione cycle activity, which is an important metabolic pathway for detoxification of hydrogen peroxide (Asada, 2000). The ascorbate peroxidase reaction is the first in AGC. This enzyme uses ascorbate to reduce $\mathrm{H}_{2} \mathrm{O}_{2}$ to water. Our data show that leaves of the plants receiving more light contained twice as much ascorbate compared to the shaded plants from Site 2.

Ascorbate is a low-molecular-weight antioxidant. The antioxidant properties of ascorbate are related to the one-electron cyclic transformation between the reduced and oxidized forms of this metabolite (Foyer, Noctor, 2011). Ascorbate reacts directly with $\mathrm{H}_{2} \mathrm{O}_{2}$, NO•, and $\mathrm{O}_{2}{ }^{-}$and can break the chain reactions of oxidation of organic molecules. Ascorbate takes part in the reduction of other low-molecular-weight antioxidants ( $\alpha$-tocopherol, glutathione, phenolic compounds) (Smirnoff, 2000; Radyukina et al., 2019). Ascorbate is a substrate for ascorbate peroxidase in cytosol and chloroplasts (Foyer, Noctor, 2011). Ascorbate plays an important role in photoprotection as a cofactor of violoxanthin de-epoxidase in the xanthophyll cycle (Conklin,
2001), and as key regulator of anthocyanin synthesis (Plumb et al., 2018). Previously, we showed that the hoary plantain plants from open habitats had the higher level of xanthophyll cycle pigment conversion compared to shaded plants (Golovko et al., 2012).

The daytime changes in the ascorbate content were detected in hoary plant leaves. Our results are consistent with the data reported by other authors (see review of Foyer, Noctor, 2011). The reduced form of ascorbate was dominant in the total ascorbate pool of the leaves from both sites, indicating the effective operation of the regeneration systems of this metabolite. As is well known, in addition to the de novo synthesis, the oxidized form of ascorbate is reduced in glutathione-dependent reaction with dehydroascorbate reductase (DHAR). According to our data, DHAR activity was higher in the leaves of plants from Site 1, where the lighting was twice higher. This indicates the importance of maintaining a high level of the reduced ascorbate in the photosynthetic cells under the high light condition. The analysis of the results revealed the presence of a statistically significant correlation $(r=0.98)$ between the ascorbate concentration and the DHAR activity in the leaves of $P$. media from Site 1. 
Glutathione is an electron donor for DHAR. Glutathione is able to reduce the sulfhydryl groups of proteins after their oxidation by $\mathrm{H}_{2} \mathrm{O}_{2}$. Glutathione is an important participant in redox signaling (Foyer, Noctor, 2011). The results of our experiments showed that the leaves of $P$. media from Site 1 contained significantly more glutathione than the leaves of shaded plants from Site 2. These data can indicate the importance of this metabolite for maintaining redox homeostasis of the photosynthetically active cells. The accumulation of glutathione in the leaves of plants from Site 1 may be due to their active photorespiration. As is well known, glycine formed during the photorespiration is a substrate to the GSH biosynthesis (Rakhmankulova, 2018). According to our data, the reduced glutathione constituted $80-90 \%$ of the total glutathione pool in $P$. media leaves.

\section{Conclusion}

We found that the content of metabolites and activity of the enzymes of the ascorbateglutathione cycle in the shaded $P$. media plants were significantly lower compared to the plants from the high light habitat. Environmental conditions and, above all, light intensity fine-tune the operation the AGC activity in plant leaves. The obtained results suggest that the effective functioning of the ascorbate-glutathione cycle is a characteristic feature of the metabolism of plant leaves and an important component of the adaptive response, which contributes to the maintenance of the redox balance in the photosynthetic cells.

\section{References}

Asada K. (2000) The water-water cycle as alternative photon and electron sinks. Philosophical Transactions of the Royal Society B: Biological Sciences, 355(1402): 1419-1431

Bellincampi D., Dipierro N., Salvi G., Cervone F., De Lorenzo G. (2000) Extracellular $\mathrm{H}_{2} \mathrm{O}_{2}$ induced by oligogalacturonides is not involved in the inhibition of the auxin-regulated rolB gene expression in Tobacco leaf explants. Plant Physiology, 122(4): 1379-1386

Bradford M.M. (1976) A rapid and sensitive method for the quantitation of microgram quantities of protein utilizing the principle of protein-dye binding. Analytical Biochemistry, 72(1-2): 248-254

Bukhov N. G., Kopecky J., Pfündel E.E., Klughammer C., Heber U. (2001) A few molecules of zeaxanthin per reaction centre of photosystem II permit effective thermal dissipation of light energy in photosystem II of a poikilohydric moss. Planta, 212(5-6): 739-748

Conklin P.L. (2001) Recent advances in the role and biosynthesis of ascorbic acid in plants. Plant, Cell \& Environment, 24(4): 383-394

Foyer C.H., Halliwell B. (1976) The presence of glutathione and glutathione reductase in chloroplasts: a proposed role in ascorbic acid metabolism. Planta, 133(1): 21-25

Foyer C.H., Noctor G. (2011) Ascorbate and glutathione: the heart of the redox hub. Plant Physiology, 155(1): 2-18

Foyer C.H. (2018) Reactive oxygen species, oxidative signaling and the regulation of photosynthesis. Environmental and Experimental Botany, 154: 134-142

Golovko T., Dymova O., Zakhozhiy I., Dalke I., Tabalenkova G. (2012) Photoprotection by carotenoids of Plantago media photosynthetic apparatus in natural conditions. Acta Biochimica Polonica, 59(1): 145-147

Halliwell B. (2006) Reactive species and antioxidants. Redox biology is a fundamental theme of aerobic life. Plant Physiology, 141(2): 312-322 
Hossain M. A., Asada K. (1984) Purification of dehydroascorbate reductase from spinach and its characterization as a thiol enzyme. Plant and Cell Physiology, 25(1): 85-92

Kampfenkel K., Vanmontagu M., Inze D. (1995) Extraction and determination of ascorbate and dehydroascorbate from plant tissue. Analytical Biochemistry, 225(1): 165-167

Nakano Y., Asada K. (1981) Hydrogen peroxide is scavenged by ascorbate-specific peroxidase in spinach chloroplasts. Plant and Cell Physiology, 22(5): 867-880

Neill S., Desikan R., Hancock J. (2002) Hydrogen peroxide signaling. Current Opinion in Plant Biology, 5(5): 388-395

Plumb W., Townsend A.J., Rasool B., Alomrani S., Razak N., Karpinska B., Ruban A. V., Foyer C.H. (2018) Ascorbate-mediated regulation of growth, photoprotection, and photoinhibition in Arabidopsis thaliana. Journal of Experimental Botany, 69(11): 2823-2835

Queval G., Noctor G. (2007) A plate reader method for the measurement of NAD, NADP, glutathione, and ascorbate in tissue extracts: Application to redox profiling during Arabidopsis rosette development. Analytical Biochemistry, 363(1): 58-69

Radyukina N. L., Mikheeva L.E., Karbysheva E. A. (2019) Low molecular weight antioxidants in cyanobacterial and plant cells. Biology Bulletin Reviews, 9(6): 520-531

Rakhmankulova Z.F. (2018) Photorespiration: its role in the productive process and evolution of C4 plants. Russian Journal of Plant Physiology, 65(3): 303-318

Ruban A.V. (2015) Evolution under the sun: optimizing light harvesting in photosynthesis. Journal of Experimental Botany, 66(1): 7-23

Smirnoff N. (2000) Ascorbate biosynthesis and function in photoprotection. Philosophical Transactions of the Royal Society B: Biological Sciences, 355(1402): 1455-1464

Vogelmann T.C., Gorton H.L. (2014) Leaf: light capture in the photosynthetic organ. The structural basis of biological energy generation. Hohmann-Marriott M.F. (ed.) Dordrecht, Springer, p. $363-377$ 